Spring 2001

\title{
Consumer Choice as the Ultimate Goal of Antitrust
}

Robert H. Lande

University of Baltimore School of Law, rlande@ubalt.edu

Follow this and additional works at: http://scholarworks.law.ubalt.edu/all_fac

Part of the Antitrust and Trade Regulation Commons, and the Consumer Protection Law Commons

\section{Recommended Citation}

Consumer Choice as the Ultimate Goal of Antitrust, 62 U. Pitt. L. Rev. 503 (2001)

This Article is brought to you for free and open access by the Faculty Scholarship at ScholarWorks@University of Baltimore School of Law. It has been accepted for inclusion in All Faculty Scholarship by an authorized administrator of ScholarWorks@University of Baltimore School of Law. For more information, please contact snolan@ubalt.edu. 


\title{
CONSUMER CHOICE AS THE ULTIMATE GOAL OF ANTITRUST
}

\author{
Robert H. Lande
}

The role of antitrust can best be understood in terms of a fundamental standard-the standard of consumer choice. The antitrust laws are intended to ensure that the marketplace remains competitive so that worthwhile options are produced and made available to consumers, and this range of options is not to be significantly impaired or distorted by anticompetitive practices.' The antitrust laws thus ensure that the economy responds to the aggregate signals of consumer demand, rather than to government directives or the preferences of individual businesses.

An optimal level of consumer choice, which has elsewhere been termed "consumer sovereignty" is the state of affairs where the consumer has the power to define his or her own wants and the ability to satisfy these wants at competitive prices. ${ }^{3}$ The concept of consumer choice even embodies some implicit notions about the rights of the individual in the broader society; it is implicitly part of the Western world's response to Marxism and the other totalitarianisms of the Twentieth Century.

How many options must be present in the market for consumer choice to be optimized? Antitrust certainty does not require that the number of options be maximized. Nor does antitrust prevent all conduct or transactions that have the effect of reducing the number of options available to consumers. Nor does the law affirmatively require the creation of options. Rather, it prevents business conduct that artificially limits the natural range of choices in the

* Venable Professor of Law, University of Baltimore School of Law. The author would like to thank Albert Foer, John Kwoka, Mary Lou Steptoe and Spencer Weber Waller for excellent suggestions, and especially, Neil W. Averitt, for important ideas and suggestions concerning every aspect of this article. The author would also like to thank Samuel Collings and Michaela Roberts for exceptional research assistance. Some of the ideas contained in this article also can be found in Neil W. Averitt \& Robert $H$. Lande, Consumer Sovereignty: A Unified Theory of Antitrust and Consumer Protection Law, 65 ANTITRUST L.J. 713 (1997).

1. Not every activity that distorts or restricts the choices that otherwise would be open to consumers is an antitnust violation, of course. The activity in question must also violate a specific antitrust statute.

2. See Neil W. Averitt \& Robert H. Lande, Consumer Sovereignty: A Unified Theory of Antitrust and Consumer Protection Law, 65 ANTITRUST L.J. 713 (1997).

3. Moreover, each product has a cluster of other attributes, such as quality and availability of related services. The free market will decide the mix of price, quality, and related attributes that consumers value most. See generally Neil W. Averitt \& Robert H. Lande, Consumer Choice: The Practical Reason For Both Antitrust and Consumer Protection Law, 10 LOY. CONSUMER L. REV. 44, 44-46 (1998). 
marketplace. ${ }^{4}$ Indeed, the law permits even some reductions, such as those resulting from some mergers, if the benefits of the action appear to outweigh the costs. ${ }^{5}$ Through these means, the antitrust laws aim to permit and preserve a sufficient, although not a perfect, array of options from which consumers may choose. ${ }^{6}$ In the short term antitrust allows consumers to choose from among the options that the free market would have produced if there had been no antitrust violation. In the long term antitrust ensures that the free market is able to undertake an optimal amount of innovation.

An antitrust policy centering around the concept of choice should be beneficial to consumers in a number of concrete ways. A choice-centered antitrust policy will support and lead to a more efficient market, ${ }^{7}$ the lowest prices, the best product quality and variety, the highest level of consumer surplus, and all the other benefits of a competitive economy. ${ }^{8}$ Thus, a

4. Some products are withdrawn from the market because not enough consumers desire to purchase them; some firms exit the market because they are not as innovative or efficient as rival firms; and some firms disappear through merger because they had not attained a minimum efficient scale. These processes reflect the ordinary workings of the marketplace. What antitrust forbids is conduct that artificially reduces the number of options directly, and without truly reflecting consumer choice.

5. Of course, it is not self-evident what will constitute an "artificial" restriction on the range of choice. Every contract restricts competition to some degree. Moving by merger from four firms to three is no more "artificial" than moving from one hundred to ninety-nine. The process is the same. All the choice cases must therefore be judged, in some way, by ascertaining the marginal value of the option that is lost through the conduct at issue, and condemning losses that are too great. This is basically a restatement of the rule of reason, and the choice description of the goals of antitrust is an application and embodiment of the rule of reason.

6. It is axiomatic that perfect competition, the perfect functioning of a competitive market, will maximize consumer choice and the welfare of consumers. Markets that diverge significantly from perfect competition may not do so, however. If a market's microeconomic characteristics differ dramatically from those required for perfect competition, a condition termed "market failure" can exist. When these problems are present, the overall level of consumer welfare may be far below what it otherwise would be, and wealth that Congress assigned to consumers may be "unfairly" acquired by firms with market power.

For an extended discussion of the concept of market failure, see Averitt \& Lande, supra note 2.

7. The antitrust statutes have as one of their goals enhancing economic efficiency. See Robert H. Lande, Wealth Transfers as the Original And Primary Concern of Antitrust: The Efficiency Interpretation Challenged, 34 HASTINGS L.J. 65 (1982), passim and especially at 106-26. The statutes serve other economic goals as well. The primary goal of these statutes is to prevent unfair transfers of wealth from consumers to firms with market power (the antitrust statutes) or to firms unfairly acting against consumer interests (the consumer protection statutes).

8. Some refinements and complexities should be added to this basic model if the circumstances require them. In some cases, the direction in which market power is exercised may be reversed, and it may be the manufacturers who need help in finding a range of marketplace options. This may be the case, for example, if a manufacturer is confronting a purchasing cartel that has agreed on a common policy to keep prices low. With appropriate adjustments, this article's orientation around the concept of consumer choice can accommodate these different circumstances. For the sake of simplicity in the following discussion, however, this article will normally speak in terms of the most common situation, which is that of ultimate 
consumer choice model of antitrust not only preserves the traditional benefits of price choices and price competition, but also goes further to recognize and protect the important elements of innovation, variety, quality, safety and other aspects of non-price competition as well.

This thesis will be elaborated in the article that follows. The discussion is divided into four principal sections. The first section demonstrates that the theory of consumer choice is embodied in the statutes and legal framework of antitrust. The second section reveals that the consumer choice theory is able to explain best, and with increasing explicitness, the existing body of decisional antitrust case law. The third section discusses why the consumer choice theory suggests that non-price competition should become a higher priority for antitrust enforcement. Finally, the fourth section identifies the communications media as one specific sector in which diversity and non-price competition are particularly important, and in which the use of consumer choice theories will be particularly appropriate.

\section{THE ANTITRUST STATUTES AND ThEORIES OF VIOLATION EMBODY A CONCERN FOR OPTIMAL LEVELS OF CONSUMER CHOICE}

The analysis must begin with the existing foundation of antitrust law. Is the proposed new model of consumer choice consistent with the statutes and the principal theories of violation that antitrust now applies? Yes, it is. Moreover, the antitrust statutes can all best be explained in terms of protecting the supply of choices in the market. Traditional theories and categories of antitrust violations-such as price fixing and related horizontal restraints, predatory pricing, anticompetitive mergers, and unreasonable vertical restraints-fit comfortably into the new model of consumer choice. The conduct at issue can distort the supply of options, in the sense of imposing restrictions on the variety of prices and products that the free market would offer. ${ }^{9}$ The antitrust laws have therefore banned this conduct.

consumers purchasing from a limited number of manufacturers.

9. Markets can fail to provide the optimal level of consumer choice for a variety of reasons. A leading scholar of the subject, Professor Edwin Mansfield, believes that perfect competition requires four conditions: product homogeneity, relatively small buyers and sellers, mobile resources, and perfect information. Significant problems in any of these areas can cause competition to be suboptimal. See EDWIN MANSFIELD, MiCROECONOMICS: THEORY AND APPLICATIONS 232-33 (5th ed. 1985).

Some of these market failures are external to the consumer, or "outside the head" of the consumer, leading to an inability of the market to provide sufficient options. Antitust law may be viewed, in economic terms, as intended to identify and compensate for this type of market failure. By contrast, market failures internal to consumers cause problems that are within the realm of the consumer protection laws. 
Specifically, price fixing and other illegal horizontal restraints ${ }^{10}$ artificially restrict the array of price options the competitive market would otherwise provide. ${ }^{11}$ Price fixing prevents consumers from having the option of the best price (or best quality or variety adjusted price) that would otherwise have been available. ${ }^{12}$

Predatory pricing similarly interferes with the array of choices that a competitive market would present. ${ }^{13}$ Predatorily low prices are good for

Both types of market failures must be avoided if the economy is to work properly; a functioning market requires both a competitive array of options to begin with, and an ability on the part of consumers to choose effectively among them.

A model economic consumer-all-knowing, all-rational, and supremely intelligent-is not vulnerable to consumer protection violations. But even this hypothetical "perfect" consumer could be vulnerable to antitrust violations. No consumer, no matter how astute, experienced, or well-informed, can protect himor herself against a cartel or illegally acquired monopoly. Except on rare occasions, ultimate consumers have no choice but to deal with a widget cartel or monopoly (or else to move to a less-desirable substitute); it generally is not cost effective for an individual consumer to build his or her own widget factory.

By thus subdividing market failures into those taking place "inside" and "outside" the head of ultimate consumers, categories of economic analysis become most nearly congruent with the kinds of consumer choice problems of concem to antitrust and consumer-protection laws and agencies. Without such market failures, as this term was broadly defined above, there could be no antitrust violations significantly harming consumer welfare. For example, in a perfect, frictionless world, businesses could still meet and fix prices, resulting in a technical violation of the antitrust laws and even in criminal penalties. But it could not substantially harm consumer welfare, because perfect information among businesses would allow some to quickly enter the price-fixed markets and compete away supracompetitive margins. In fact, if other businesses in the industry possessed information that truly was perfect, they would know that prices were about to rise due to a price-fixing scheme and would have an incentive to enter quickly to obtain a share of the monopoly profits. This competition, if it occurred quickly and perfectly, would soon drive prices down to only an insignificant fraction above the competitive level. Consumer welfare thus would not be significantly lowered.

What makes antitrust injury possible in these circumstances is the presence of external market failures. Market imperfections such as search costs, faulty information, time lags, and sunk costs can enable a cartel to keep prices elevated for a significant period. For an extended discussion of market failure issues in an antitrust and consumer protection context, see Averitt \& Lande, supra note 2, at 722-34.

10. Of course, not every horizontal restraint is illegal. A joint venture that increases industry-wide innovation, for example, is generally procompetitive and legal. See A.B.A. ANTITRUST LAW SECTION, ANTITRUST LAW DEVELOPMENTS (THIRD) (3d ed. 1992); HeRBERT HovenKaMP, FEDERAL ANTTTRUST POLICY 140-240 (1994).

11. Price fixing also can, to a small degree, distort consumer choice. A few consumers might not purchase if they knew that prices were fixed. The principal reason why the antitrust laws condemn price fixing, however, is because it eliminates the option of price competition from the market.

12. Price fixing also has a number of indirect anticompetitive effects. It shields inefficient firms from hard competition. See Lande, supra note 7, at 78-79. It also causes allocative inefficiency and a transfer of wealth from consumers to producers. $1 d$. at 72-77.

13. For an excellent discussion of predatory pricing theory and case law, see James D. Hurwitz \& William E. Kovacic, Judicial Analysis of Predation: The Emerging Trends, 35 VAND. L. REv. 63 (1982), and HOVENKAMP, supra note 10, at 298-328. 
consumers only in the short run. In the long run, ${ }^{14}$ such prices threaten to eliminate from the marketplace certain firms that provide options that consumers would actually prefer.

Mergers provide yet another example of a traditional antitrust violation that has both direct, short-run effects and indirect, long-run effects on the range of options available to consumers. An anticompetitive horizontal merger can directly eliminate significant competition, as expressed in terms of diminished options on price, product quality, or product variety. It can also have the long-run or indirect effect of making industry-wide collusion easier or more probable, ${ }^{15}$ potentially leading to the elimination of still more options that consumers might prefer.

Resale price maintenance (RPM) and other vertical restraints can also have the effect of limiting consumer choice. RPM directly restricts the price options open to consumers, limiting them to the manufacturer's preferred price. ${ }^{16}$ Non-price restraints, such as exclusive dealing and exclusive territories, have similar effects, often significantly restricting downstream firms in the choices that they can offer to consumers. ${ }^{17}$ Of course, each of these practices also can cause significant, potentially offsetting procompetitive effects, ${ }^{18}$ and if they are imposed by firms without market power the possibility that their anticompetitive effects (i.e., their option distortions) will be significant is probably quite small. ${ }^{19}$ Nonetheless, it is the possibility of anticompetitive option loss that makes these transactions of concern to antitrust.

A focus on choice also explains why certain practices that raise rivals' costs are undesirable. ${ }^{20}$ The rivals' higher costs force them to raise their

14. This assumes the existence of effective barriers to entry, for without them similar firms would be able to enter and offer the desired options.

15. HoVENKAMP, supra note 10 , at $455-66,479-88$.

16. J.R. Gould \& B.S. Yamey, Professor Bork on Vertical Price Fixing, 76 YALE LJ. 722, 729 (1967) (stating that 'r.p.m. [resale price maintenance] restricts the range of consumers' choice. ... The restriction of the range of consumers' choice is prima facie against public policy.") (emphasis in original). For an overview of these effects, see Alan A. Fisher et al., Do the DOJ Vertical Restraints Guidelines Provide Guidance?, 32 ANTITRUST BULL. 609, 615-23 (1987).

17. Fisher et al., supra note 16 , at 615-23.

18. Id. at 615-16. Moreover, these offsetting efficiencies can sometimes be characterized as attempts to overcome market failures. See id. (discussing the point of sale "free-rider" problem).

19. Id. at 615-16. For this reason, non-price vertical restraints are judged under a rule of reason standard. See Cont'l T.V., Inc. v. GTE Sylvania, Inc., 433 U.S. 36 (1977). Many believe that RPM also should be judged under the rule of reason or that it even should be deemed per se legal. See Fisher et al., supra note 16 , at $615 \mathrm{n} .18$.

20. See Thomas G. Krattenmaker \& Steven C. Salop, Anticompetitive Exclusion: Raising Rivals' Costs to Achieve Power Over Price, 96 YALE L.J. 209 (1986). 
prices (or reduce their investment in product improvement and innovation), which enables the predator to raise its own prices (or reduce its optionenhancing investment in research and innovation). ${ }^{21}$ Consumers thus lose the choice of purchasing better or more competitively priced products. ${ }^{22}$

In short, antitrust law and legal theory can readily be understood as a way of protecting the variety of consumer options in the marketplace. ${ }^{23}$

\section{THE ANTITRUST CASE LAW EMBODIES A CONCERN FOR OPTIMAL LEVELS OF CONSUMER CHOICE}

It is not just the statutes and legal theory of antitrust that are best explained in terms of consumer choice. A large number of cases are best explained in these terms as well.

Sometimes price is the only concern of an antitrust violation, such as those circumstances when a cartel raises prices to consumers. In these cases, the courts may simply condemn the price-fixing. These courts appear to focus on price, but even here they implicitly treat the defendants' conduct as a form of harm to what would otherwise have been the variability and choices in the price terms of a transaction.

On other occasions the case law has been quite explicit that optimal levels of consumer choice are the ultimate concern. Such statements are found in virtually every area of antitrust.

For example, in United States v. Philadelphia National Bank, ${ }^{24}$ the Court discussed the anticompetitive effects of undue concentration and the reason

21. For a thorough explanation and discussion of the necessary prerequisites to this conduct, see Thomas G. Krattenmaker et al., Monopoly Power and Market Power in Antitrust Law, 76 GEO. L.J. 241, 248-53, 265-69 (1987).

22. As an additional example, see Jacob Inwald \& Anthony A. Carli, Jr., Note, The Treatment of Delivery Services Under Section 2(e) of the Robinson-Patman Act, 51 GEO. WASH.L. REV.727, 727 (1983) (stating that the legislative history of the Robinson-Patman Act evidences that Congress believed "that the public interest in competition and consumer choice would suffer from the demise of small business, [and it therefore] enacted the Robinson-Patman Act in 1936 ...").

23. Depending on the specific antitrust principle involved, improper restrictions on consumer options may occur either directly as a result of firms' actions vis-a-vis their customers, or indirectly as a result of firms' actions vis-a-vis their competitors. For example, if a firm with market power over a product will sell it only when packaged with a second product, consumers' choices are directly reduced and distorted. The firm's action vis-à-vis its customers may be condemned as an illegal tying arrangement. Alternatively, suppose that a firm merges with all of its competitors and then raises prices to a monopoly level. While monopoly pricing and the production of only a single brand is not illegal, the process by which the firm acquired this power to constrain options certainly might be illegal. The firm's actions vis-a-vis its competitors may then be condemned as involving anticompetitive mergers.

24. 374 U.S. 363 (1968). 
underlying the presumption that unduly large mergers were anticompetitive. The Court expressed a concern with possible adverse effects of the merger on "price, variety of credit arrangements, convenience of location, attractiveness of physical surroundings, credit information, investment advice, service charges, personal accommodations, advertising, miscellaneous special and extra services ...." 25 The Court thus explained its fear of undue concentration in terms of a reduction in either price or non-price competition that might harm consumers. ${ }^{26}$ The Court wanted consumers to be able to choose freely on the basis of any price or non-price issue important to them. The Court feared that a merger might lead to an incipient reduction of some aspect of consumer choice-and not necessarily in the price aspects alone. ${ }^{27}$

This same concern for consumer choice has also been expressed in monopolization cases, ${ }^{28}$ attempted monopolization cases, ${ }^{29}$ as well as cases

25. See id. at 368 .

26. Id.

27. See also Brown Shoe Co. v. United States, 370 U.S. 294, 345 n.72 (1962) (The discussed legislative history of Section 7 of the Clayton Act and found that "expansion through merger is more likely to reduce available consumer choice while providing no increase in industry capacity, jobs or output. It was for these reasons, among others, Congress expressed its disapproval of successive acquisitions.").

28. See Aspen Skiing Co. v. Aspen Highland Skiing Corp., 472 U.S. 585, 610 (1985) (finding the defendant's behavior to be based on discouraging business with the plaintiff, and thereby not allowing "consumers to make their own choice on these matters of quality"); Berkey Photo v. Eastman Kodak Co., 603 F.2d 263, 287 (2d Cir. 1979) (The court found that whether a monopolist creates an inferior product is irrelevant, and the "only question that can be answered is whether there is sufficient demand for a particular product to make its production worthwhile, and the response, so long as the free choice of consumers is preserved, can only be inferred from the reaction of the market."); GAF Corp. v. Eastman Kodak Co., 519 F. Supp. 1203, 1227 (S.D.N.Y. 1981) (The court discussed unlawful uses of monopoly power such as using monopoly power in one market to distort consumer choice in another market. A monopolist's use of monopoly power in one market to coerce consumer choice of its new product in the same market is also unlawfully coercive.); Hewlett-Packard Co. v. Boston Scientific Corp., 77 F. Supp. 2d 189, 199 (D. Mass. 1999) (The court denied defendant's motion to dismiss plaintiff's Sherman Act Section 2 claim, stating "[plaintiff] claims that [defendant] injured the competitive process by engaging in predatory acts which drove [plaintiff] out of the market for both consoles and catheters, depriving consumers of a meaningful choice of competing innovative products. If proven, these allegations are sufficient to show that [defendant] injured competition, which is exactly the type of injury the antitrust laws were designed to prevent.").

29. See Ghem, Inc. v. Mapco Petroleum, 767 F. Supp. 1418, 1422 (M.D. Tenn. 1990) (No antitrust violation occurred because plaintiff failed "to suggest how [defendant's] pricing practices have hindered consumer choices."); Gowan Car Care Ctr. v. Murphy Oil USA, 2000 WL 1477789, at *8, 230 F.3d 1358 (6th Cir. 2000) ("Plaintiffs have failed to suggest how [defendant's] pricing practices have hindered consumer choices. In fact, it seems quite clear that consumers have benefitted ...."); Sterns Airport Equip. v. FMC Corp., 170 F.3d 518, 531 (5th Cir. 1999) ("[T] he [pricing] conduct at issue did not violate the antitnust laws. It was merely vigorous competition, and the ultimate consumer of the product at all times retained the power of choice."); General Indus. Corp. v. Hartz Mountain Corp., 810 F.2d 795, 804 (8th Cir. 1987) (The jury could make the reasonable inference that the defendant's practice attempted to monopolize 
involving agreements among competitors, ${ }^{30}$ vertical mergers, ${ }^{31}$ boycotts and joint ventures, ${ }^{32}$ tying, ${ }^{33}$ refusals to deal,${ }^{34}$ and vertical restraints. ${ }^{35}$ The model

the relevant market, and thereby "preempt[ed] any opportunity for the consumer to make a real choice.").

30. See NCAA v. Board of Regents, 468 U.S. 85, 102 (1984) (Conduct is deemed procompetitive where the "[defendant's] actions widen consumer choice-not only the choices available to sports fans but also those available to athletes ... ."); FTC v. Indiana Fed'n of Dentists, 476 U.S. 447, 459 (1986) (The Court found that a horizontal agreement to restrain trade which limits "consumer choice by impeding the 'ordinary give and take of the market place,' cannot be sustained under the Rule of Reason.") (quoting Nat'1 Soc'y of Prof. Eng'r v. United States, 435 U.S. 679, 692 (1978)); United States v. Nat'l Soc'y of Prof. Eng'r, 404 F. Supp. 457, 460 (D.D.C. 1975), rev'd on other grounds, 935 U.S. 679 (1978) ("[S]ince alternative sources (e.g., non-licensed professional engineers) are non-existent, the impact upon the public of defendant's pricing restraint is plain. Without the ability to utilize and compare prices in selecting engineering services, the consumer is prevented from making an informed, intelligent choice.").

31. See S.C. Communis. v. FCC, 56 F.3d 1484 (D.C. Cir. 1995) (finding that the vertical merger was not in violation of antitrust laws, as the FCC determined the pro-competitive effects substantially outweighed the anti-competitive effects). See also In re Applications of McCaw \& AT\&T Co., 9 F.C.C.R. 5386, 1994 WL 511406 (Sept. 19, 1994).

32. Full Draw Prod. v. Easton Sports Inc., 182 F.3d 745, 755 (10th Cir. 1999) (For purposes of standing on the claimed antitrust injury, "[t]he effect of defendants' alleged boycott was not to increase competition between the two trade shows, but rather to distort and ultimately reduce competition by destroying one source of output ... and thereby limiting consumer choice to the other source of output. ..."); Wilk v. AMA, 895 F.2d 352, 360 (7th Cir. 1990) (The Circuit Court affirmed the District Court's opinion that the defendant's boycott was illegal, as "[i]t is anticompetitive and it raises costs to interfere with the consumer's free choice to take the product of his liking. ...") (citing Wilk v. AMA, 671 F. Supp. 1495, 1478-79 (N.D. Ill. 1987)):

33. Jefferson Parish Hosp. Dist. No. 2 v. Hyde, 466 U.S. 2, 27 (1984) ("Tying arrangements need only be condemned if they restrain competition on the merits by forcing purchases that would not otherwise be made."); Roy B. Taylor Sales, Inc. v. Hollymatic Corp., 28 F.3d 1379, 1384 (5th Cir. 1994) (finding that a tying arrangement did not exist and further stating that in tying arrangements, "a foreclosure of choice to an ultimate consumer appears to be the principal key-to a tie that is illegal per se"); Berkey Photo Inc. v. Eastman Kodak Co., 603 F.2d 263, 270-71 (2d Cir. 1979) (discussing the 1954 FTC investigation of Kodak's "tie-in" arrangement requiring Kodak to process film purchased by consumers and stating "[c]onsumers had little choice but to purchase Kodak film, and in so doing they acquired the right to have that film developed and printed by CP\&P at no further charge"); Northern Pac. Ry. v. United States, 356 U.S. 1, 6 (1958) (In tying arrangements, "buyers are forced to forego their free choice between competing products."); Rosebrough Monument Co. v. Mem'l Park Cemetery Ass'n, 666 F.2d 1130, 1138, 1139 (8th Cir. 1981) (Defendant trade association's practice of providing members with the exclusive right to "prepare the foundation, place, and maintain monuments in their respective cemeteries" "stunts rather than develops trade within the cemetery industry and limits consumer choice and the free flow of commerce.").

34. Image Technical Servs. Inc. v. Eastman Kodak Co., 125 F.3d 1195, 1212 (9th Cir. 1997) (One factor leading to conclusion that the defendant's practices were actionable was that 'Kodak's market share in the equipment market further limit[ed] choices by consumers.").

35. See Barry v. Blue Cross, 805 F.2d 866, 873 (9th Cir. 1986) (The court found that the vertical agreement between physicians and the defendant insurance company to refer patients to defendant's participating physicians was not a violation of antitrust law and actually had the pro-competitive effect of "offer[ing] consumers the added choice of health care services subject to a sort of central 'quality control."”). 
presented here thus becomes a means of explaining, interpreting, and applying a long line of legal precedents.

\section{EVIDENCE OF THE NEW PARADIGM: UNITED STATES V. MICROSOFT ${ }^{36}$}

Although this article suggests that antitrust should explicitly shift to an analytical model of consumer choice, there is good reason to believe that the law is already evolving in that direction, perhaps without being aware of it. Consider, for example, that this era's most prominent antitrust case, the Microsoft litigation, is being fought primarily in "choice" terms.

From the Findings of Fact $^{37}$ to the recently filed appellate briefs, ${ }^{38}$ the main focus of the Microsoft case has not been the price or cost of production of any current product. ${ }^{39}$ The price of an Internet browser as a factor in itself, for instance, is simply not a high priority. ${ }^{40}$ The central fear underlying the case is the possibility that innovation, new products, and eventual consumer choice will be diminished. ${ }^{41}$

Judge Jackson's decision centered around the concept of "choice" rather than price, efficiency, or social/political effects. ${ }^{42}$ In his Findings of Fact,

36. In deciding this case, Judge Thomas $P$. Jackson bifurcated the factual and legal findings into two reported decisions. The Findings of Fact are available at United States v. Microsoft, 84 F. Supp. 2d 9 (D.D.C. 1999), and the Conclusions of Law are available at United States v. Microsoft, 87 F. Supp. 2d 30 (D.D.C. 2000). I am grateful to Michaela Roberts for excellent assistance with the research and analysis that went into this section.

37. See United States v. Microsoft Corp., 84 F. Supp. 2d 9 (D.D.C. 1999).

38. See United States v. Microsoft Corp., Brieffor Appellees United States and the State Plaintiffs (Jan. 12, 2001), available at http://www.usdoj.gov/atr/cases/f7200/7230.htm (last visited Mar. 10, 2001) (choose Word Perfect version); United States v. Microsoft Corp., Brieffor Defendant-Appellant (Nov. 27, 2000), available at http://ecfp.cadc.uscourts.gov/MS-Docs/1602/0.pdf (last visited Jan. 19, 2001).

39. The Government asserted, in the United States' brief, for example, in the heading of a major section of its Joint Proposed Conclusions of Law: "A Monopolist May Not Deliberately Take Actions That Erect Obstacles To Consumer Choice On The Merits ..." (Heading, Section I(B)(1). Another heading asserted that "Microsoft Took Costly Actions That Impaired Consumer Choice ..." (Heading, Section I(B)(2)). Microsoft, by contrast, stressed its innovations; it asserted that its conduct was only meeting the demands of consumers, and it alleged that its actions benefitted consumers in numerous ways, most of which had nothing to do with price. Summary of Proposed Findings of Fact at 2-3.

40. In antitrust, alarm bells normally go off at the prospect of a firm raising the price of something by $20 \%$ due to anticompetitive conduct. This is not the case in the computer area, however, because prices are typically decreasing. Innovation and the enhanced choices that innovation makes possible are normally more important than price effects in these markets. See also supra note 12.

41. See supra notes $39-40$.

42. Judge Jackson's Findings of Fact in the Microsoft case ends with a section titled "The Effect on Consumers of Microsoft's Efforts To Protect The Applications Barrier To Entry." See Microsoft, 84 F. Supp. $2 \mathrm{~d}$ at 110. This section discusses the deleterious effects of Microsoft's conduct on consumer choice or innovation in almost every paragraph. He did not, however, even make a single finding that Microsoft 
Jackson defined the relevant market in terms of consumers' inability to substitute other products for Microsoft's operating systems. ${ }^{43}$ Jackson described Microsoft's market power in terms of consumer preference for various features. ${ }^{44}$ Finally, on the issue of whether monopoly power had been illegally maintained, Judge Jackson used consumer choice as the central point of his finding that Microsoft illegally maintained its power by erecting an applications barrier to entry. ${ }^{45}$

Consumer choice also figured prominently in the trial court's finding that Microsoft had improperly tied its Internet browser with the Windows 98 operating system. Judge Jackson found that these actions in large part ignored consumer demand. ${ }^{46}$ Under the "consumer-demand" test, he found that the Internet browser and operating systems were separate products. ${ }^{47}$ Jackson also found that the tying of these products resulted not in a convenience for the consumer, but rather a significant harm to consumer choice. ${ }^{48}$ Jackson concluded his findings of fact by remarking that, "the ultimate result [of Microsoft's actions] is that some innovations that would truly benefit consumers never occur for the sole reason that they do not coincide with Microsoft's self-interest.",49

raised the price of any of its products to specific levels. Pricing issues were minor ones in his Findings of Fact and Conclusions of Law.

43. See Microsoft, 84 F. Supp. 2d at 15. Jackson stated, "a consumer would not obtain a satisfactory substitute for an Intel-compatible PC operating system even if he purchased a server, since server operating systems lack the features - and support for the breadth of applications- that induce users to purchase Intelcompatible PC operating systems." Id.

44. See id. at 19. Judge Jackson found, "[t]he consumer wants an operating system that runs not only types of applications that he knows he will want to use, but also those types in which he might develop an interest later." Id.

45. Jackson found that

[t]he actions that Microsoft took against Navigator hobbled a form of innovation that had shown the potential to depress the applications barrier to entry sufficiently to enable other firms to compete effectively against Microsoft in the market for Intel-compatible PC operating systems. That competition would have conduced to consumer choice and nurtured innovation.

Id. at 111-12.

46. See id. The decision states,

By refusing to offer those OEMs who requested it a version of Windows without Web browsing software, and by preventing OEMs from removing Internet Explorer-or even the most obvious means of invoking it-prior to shipment, Microsoft forced OEMs to ignore consumer demand for a browserless version of Windows.

Id. at 111.

47. See id. at 48 .

48. See id. at 111.

49. Microsoft, 84 F. Supp. $2 \mathrm{~d}$ at 112. 
In his conclusions of law, Jackson clearly stated again that consumer choice was the crucial factor in the case. ${ }^{30}$ For example, he found that Microsoft was willing to injure consumer choice to protect its monopoly position. $^{51}$ As to the alleged tying agreement, Jackson found that not only were the operating system and browser separate products because of separate demand, ${ }^{52}$ but also Microsoft's actions effectively interfered with that choice. $^{53}$

The recently filed appellate briefs also illustrate the importance of consumer choice. While the government and Microsoft disagree as to the effects of Microsoft's actions, both agree that securing optimal levels of consumer choice is the cornerstone of antitrust law. ${ }^{54}$

The government, in addition to presenting Judge Jackson's Findings of Fact and Conclusions of Law in terms of consumer choice generally, ${ }^{55}$ argues that the tying violation had a particularly important effect on choice: "Microsoft's binding of [Internet Explorer] to Windows, in short, was pure bolting, which caused the very harms targeted by tying law: substantial impairment of consumer choice on the merits between browsers . . .."56

50. See Microsofi, 87 F. Supp. $2 \mathrm{~d}$ at 44 . Judge Jackson held, "Microsoft's anticompetitive actions trammeled the competitive process through which the computer software industry generally stimulates innovation and conduces to the optimum benefit of consumers." Id.

51. "Microsoft was willing ... to obstruct the development of Windows-compatible applications if they would be easy to port to other platforms and would thus diminish the applications barrier to entry." Id.

52. Id. at 50. The decision states:

Considering the "character of demand" for the two products, as opposed to their "functional relation," Web browsers and operating systems are "distinguishable in the eyes of buyers." Consumers often base their choice of which browser should reside on their operating system on their individual demand for the specific functionalities or characteristics of a particular browser, separate and apart from the functionalities afforded by the operating system itself. Id. (citations omitted).

53. Id. at 51. Judge Jackson stated "[ $[$ ] his Court concludes that Microsoff's decision to offer only the bundled- 'integrated' - version of Windows and Internet Explorer derived not from technical necessity or business efficiencies; rather, it was the result of a deliberate and purposeful choice to quell incipient competition before it reached truly minatory proportions."

54. See Brief for Appellant-Defendant, supra note 38, at 12 (stating "[c]onsumers-the intended beneficiaries of the antitrust laws-have greatly benefitted from Microsoft's efforts to offer improved products at attractive prices") (emphasis added); Brieffor Appellees-United States and the State Plaintiffs, supra note 38, at 121 ("Microsoft violated the antitrust laws through a wide range of predatory and exclusionary acts that maintained its operating system monopoly by protecting and raising the applications barrier to entry. That illegal conduct restricted consumer choice and deterred innovation in the personal computer industry.").

55. See Brieffor Appellees-United States and the State Plaintiffs, supra note 38, at 3, 8-9, 11-12, 19-20, 24-25, 27, 42-43 of argument section.

56. See id. at 44 . 
Similarly, the government argued that Microsoft's actions in maintaining monopoly power effectively foreclosed consumers' opportunity to make a reasoned choice in the marketplace. ${ }^{57}$ Finally, on the issue of remedy, the government argued that divestiture was required because: "Injunctive relief crafted for the long term necessarily would involve complex and highly intrusive restrictions on Microsoft's conduct, might result in regulation rather than consumer choice determining market outcomes ...."s8

Strikingly enough, Microsoft's argument, while on the opposite side in substance, adopted a similar frame of reference in asserting that the firm's actions stimulated innovation and eventual consumer choice. ${ }^{59}$ For example, Microsoft stated that "the market position of Windows was created by, and is dependent on, consumer demand, not Microsoft's control of total output."60 As to the alleged tying arrangement, Microsoft argued that, "[t]here are clear benefits to Microsoft's integrated design."61 The firm agreed that tying products would be unlawful where consumers are forced to "forego their free choice." ${ }^{62}$ But Microsoft argued that offering the Internet browser for free "has not forced anyone to purchase ... a separate tied product"; for this reason it has "resulted in no injury to competition."

The ultimate point to note here is that the Microsoft case is being argued in terms of consumer choice, and not in terms of price. The case thus dramatically illustrates how consumer choice is emerging as an explicit paradigm for antitrust.

\section{NON-PRICE COMPETITION SHOULD BECOME A HIGHER PRIORITY FOR ANTTTRUST ENFORCEMENT}

The protection of consumer choice generally, not just low price choice in particular, should more explicitly become the focus of antitrust law. In most respects, a choice orientation to antitrust will merely result in a continuation

57. See id. at 84 . The government stated that "maintaining this monopoly necessarily generates future harm to consumers, in addition to the harm they already had experienced through the constriction of their choices." Id.

58. Id. at 125.

59. See Brief for Appellant-Defendant, supra note 38, at 2 (arguing that Microsoft's integration of an Internet browser with its operating system and free distribution of that integrated product "clearly benefitted [consumers] ....").

60. Id. at 93.

61. Id. at 74.

62. Id. at 80 .

63. Id. at 80,83 . 
of current enforcement policies. But in a few situations it will extend protections into new areas that are important to consumers. ${ }^{64}$

The enforcement agencies have already recognized the importance of preserving non-price options in sufficiently clear circumstances. They have recognized that firms can compete on dimensions other than price-such as innovation, product variety, safety, and product quality. ${ }^{65}$ Indeed, for some products, quality competition may be the most important kind. In the market for bulletproof vests, for example, buyers certainly care much more about product reliability than about product price. For this reason, the FTC was concerned when an association of bulletproof vest manufacturers adopted a rule restricting comparative advertising. The association's rule had declared that it was unethical for any member to represent that another member's vests had failed certification testing, even if the advertising claim were true. The FTC had no difficulty accepting a consent agreement against this practice, because elimination of the advertising ban would tend to foster useful quality competition. ${ }^{66}$

In more ordinary antitrust cases, however, where the elimination of nonprice competition is not so obviously central to the violation, the enforcement agencies have sometimes tended to de-emphasize this factor. ${ }^{67}$ For example, the conventional antitrust analysis under Section 7 of the Clayton Act concentrates almost exclusively on the price effects of a merger: the merger is to be condemned if it is likely to lead to higher prices. Even if it has no significant effect on price, however, an anticompetitive merger might adversely affect consumers with respect to other forms of competition. A

64. A choice analysis may or may not call for stricter antitrust enforcement in a particular industry, but it will never call for looser enforcement. For example, this analysis as applied to mergers will require, in all cases, at least the number of firms required by the Merger Guidelines, in order to protect the basic range of price options. However, to protect the non-price options, some further number of firms may sometimes be required.

65. Non-price competition is often extremely important to both businesses and consumers. Such competition can take place in terms of innovation, scheduling, service, convenience, or product variety. Such factors can be especially important in particular industries. At certain times in the past, for example, the airlines appeared to compete in large part in terms of scheduling and convenience. Also, members of the motion picture industry still compete in terms of product innovation. These qualities may or may not be readily expressed in terms of price, but they definitely affect the range of choice in the marketplace and thus are easily comprehended under a formula that focuses on the factor of choice.

66. Personal Protective Armor Association, 59 Fed. Reg. 19019 (1994).

67. See Int'l Ass'n of Conference Interpreters, Docket No. 9270, slip op. at 35-36 (Feb. 19, 1997), available at http://www.ftc.gov/os/adjpro/d9270/index.htm (The court found violations on price fixing and other per se theories, but dismissed for insufficient proof the charges involving non-price restraints judged under the rule of reason. "With the exception of three findings . . . all of the effects discussed by the ALJ stem from the price-related restraints."). 
focus on consumer choice as a goal will make it easier for enforcement agencies to consider the merger's effects in these areas. Moreover, given that competition in these dimensions might be affected at concentration levels different from those most relevant for pure price considerations, attention to consumer choice may sometimes suggest challenges to mergers that would not otherwise be illegal.

Choice would represent a change of emphasis from traditional merger analysis. Although merger analysis makes pro forma bows toward other dimensions of competition, the analysis promptly returns to price. The federal Merger Guidelines, for example, have a section titled "Purpose and Underlying Policy Assumptions of the Guidelines," a dozen references in the text to "price," the "transfer of wealth from buyers to sellers," and similar monetary concepts. ${ }^{69}$ Only a single footnote suggests that merger policy includes non-monetary concerns. ${ }^{70}$ The National Association of Attorneys' General (NAAG) State Merger Guidelines reflect a similar emphasis. They concede in a footnote that consumers can be harmed by oligopoly behavior "on terms of trade other than price," "71 but also declare, more fundamentally, that the "central purpose" of merger law "is to prevent firms from attaining market or monopoly power, because firms possessing such power can raise prices to consumers above competitive levels . . ."72 Both the federal and NAAG Merger Guidelines therefore permit consideration of non-price elements of competition, but both are structured in such a way as not to particularly encourage that exercise.

Some elements of non-price competition might be captured through use of the concept of "quality-adjusted price." Again, however, the Guidelines are not structured to particularly encourage that approach. Moreover, "qualityadjusted price" may be a difficult concept to apply in concrete situations where the non-price components of competition are particularly important, or where they take subtle or complex forms.

68. Department of Justice and Federal Trade Commission Horizontal Merger Guidelines, 62 ANTITRUST \& TRADE REG. REP. (BNA) $\$ 0.1$, at 107 (Apr. 2, 1992).

69. Id.

70. "Sellers with market power also may lessen competition on dimensions other than price, such as product quality, service, or innovation." $l d$. at n.6.

71. The footnote actually elaborates this consideration at somewhat more length than the federal guidelines. It reads: "Tacit or active collusion on terms of trade other than price also produces wealth transfer effects. This would include, for example, an agreement to eliminate rivalry on service features or to limit the choices otherwise available to consumers." 4 TRADE REG. REP. (CCH) \ 13,405, at 21,186 n.17.

72. Id. at 21,185 . 
In looking for possible harms to non-price competition, antitrust decisionmakers need to be careful and cautious. The consumer choice orientation will remind the antitrust agencies of the relevance of non-price factors. Indeed, harms to non-price competition are already covered by the Clayton Act and have already informed decisions in merger cases. ${ }^{73}$ However, the choice model does not alter or expand the actual reach of Section 7.

Caution is particularly appropriate here because price competition usually serves as a reasonably good proxy for non-price competition. Once a particular market is price-competitive, in other words, it may often offer selfequilibriating levels of competition in other dimensions as well. Consider, for example, a post-merger market that is price-competitive but that, as the result of a merger, no longer produces the optimum level of product variety. If consumers truly want more variety, and if the firms are truly competitive, then they will soon begin to extend their product lines by introducing a greater number of models and variants to the market.

Sometimes, however, price competition alone may provide insufficient protection. This problem will be most likely to arise with respect to certain kinds of intellectual property, some of which can play a competitive role only in an environment of organizational independence.

\section{CONSUMER CHOICE AND THE MEDIA}

The most important area where optimal levels of price competition may be insufficient to provide optimal levels of diversity and innovation may be the independent editorial programming of a communications medium. If one communications medium were to buy another of the same kind, the acquisition might not concentrate the market sufficiently to threaten price competition. Being competitive, the market might also soon produce the product menu that consumers desire, in terms of types and formats of shows. But the market would inevitably sustain a loss of editorial diversity. This loss cannot be recreated through the normal mechanism of non-price competition among the surviving firms; the new products would necessarily bear the editorial stamp of their common owner. ${ }^{74}$ This scenario suggests that media mergers should

73. See, e.g., FTC v. PPG Indus., Inc., 798 F.2d 1500 (D.C. Cir. 1986) (preliminarily enjoining merger of manufacturers of high technology aircraft transparencies, who competed, among other ways, in new product development).

74. The common editorial stamp may be particularly troublesome if the different communications companies appear to be competing and if consumers therefore do not have their critical guard up. This might happen if their underlying common ownership is not generally known, and if they are structured to 
be carefully scrutinized for loss of non-price competition along the dimension of diversity in programming. Where that loss is sufficiently severe, ${ }^{75}$ such mergers should be challenged under the Clayton Act, even if there has been no showing of harm to price competition.

If anything, as an exercise of prosecutorial discretion the antitrust laws should be applied more strictly when the media is involved. We can live with too few manufacturers of aluminum, canned food, or paper better than we can live with too few independent sources of news. ${ }^{76}$ Free and full competition in the news market is fundamental to a democracy. ${ }^{77}$

Suppose, for example, that the country had only four book publishers, and that two of them merged. This merger might not lead to a loss of price competition, or to a narrowing in the range of price options. ${ }^{78}$ On the other

pursue different formats or market niches in a way that suggests different editorial viewpoints. For example, on November 2, 1999, American Media purchased Globe Communications for $\$ 105$ million. This merger resulted in the combined ownership of three of the best known supermarket tabloids: the National Enquirer, the Star, and the Globe. David Pecker, chief executive and chairman of American Media, stated that he intended to develop clear editorial differences among the three papers, giving the company the ability to compete at each level of sophistication with the market's newer competitors. See Paul Farhi, Three-Headed Baby? Rival Tabloids Joined in Corporate Deal, WASH. POST, Nov. 3, 1999, at C01.

75. Antitrust enforcers could not challenge every merger involving intellectual property on the grounds that, by removing the products of the acquired firm as an independent force in the market, the merger would necessarily impair consumer choice. True, in some linguistic sense every merger of a product involving some element of creativity removes a choice from the market. The incorporation of Oldsmobile into General Motors deprived those consumers who preferred the independent Oldsmobile design department of that choice. This deprivation of choice alone cannot be the basis for illegality, however, for such an argument would prove too much. It would result in the illegality of every merger involving nonfungible products, regardless of how small the element of independence in the product or how much or how little importance consumers attach to that independence in the context of the particular product involved. Congress cannot have intended this to constitute the "substantial" lessening of competition that is the concern of Section 7. Actually figuring out how to express the threshold of substantiality for different types of non-price competition would be a difficult job, of course, but it is one that needs to be undertaken if antitrust is to come to grips with this set of issues.

76. This is one of the principal reasons for the enactment of the Newspaper Preservation Act. Competing newspapers are permitted to form Joint Operating Agreements in order to save money and avoid a downward spiral that might result in bankruptcy. They are required to do so, however, in a manner that preserves editorial competition and reportorial competition.

77. As Robert Pitofsky, Chair, Federal Trade Commission, observed:

[If] you have issues in the newspaper business, in book publishing, news generally, entertainment, ... you want to be more careful and thorough in your investigation than if the very same problems arose in cosmetics, or lumber, or coal mining. [If] somebody monopolizes the cosmetics fields, they're going to take money out of consumers' pockets, but the implications for democratic values are zero. On the other hand, if they monopolize books, you're talking about implications that go way beyond what the wholesale price of the books might be.

Alec Kleil, A Hard Look at Media Mergers, WASH. POST, Nov. 29, 2000, at E1, available at http://www.washtech.com/news/merger/5513-1.html (last visited Apr. 4, 2001).

78. An absence of price effects is particularly likely if we assume relatively low entry barriers and 
hand, it might well lead to a quantifiable loss of editorial diversity, and thus to a narrowing of the competing marketplace options expressed in terms of the types of titles offered.

An example of what can happen when inadequate competition in the media sector leads to inadequate choice occurred during the last Presidential election. At almost the same time, around 8:00 p.m. election night, every major network declared that Vice President Gore had won the Florida primary. ${ }^{79}$ Within the next two hours, however, every network had withdrawn their predictions and declared the state "too close to call." Very early Wednesday, most declared Governor Bush the winner. Then came the final mass switch back to "too close to call." The networks called it wrong twice: once for each candidate. ${ }^{80}$

Why the uniformity of (wrong) results? This outcome can be explained by a lack of competition. All the "competing" major networks were actually collaborating with one another, and they called their collaboration the Voter News Service. ${ }^{81}$ Since they all relied upon the same (mistaken) pooled data, they naturally all made the same error. ${ }^{82}$

Until the 1964 election, the major news organizations did their own exit polling and made their election predictions independently. ${ }^{83}$ They subsequently combined more and more of their operations until, in 1990, the six major T.V. news organizations-ABC, CBS, NBC, Fox, CNN and the Associated Press-decided to combine the entirety of their exit polling and news prediction operations. ${ }^{84}$ Their motivation was, of course, to save money. During the 2000 election there was still some room for interpretation on the margin of the results and predictions made by the Voter News Service. But

a strategy of limit pricing by the firms in the market.

79. See James V. Grimaldi, Battle of the Titans, WASH. POST, Nov. 27, 2000, at E8; Kathy Chen, Antitrust-Advocacy Group Seeks Breakup of Voter News Service, Citing Florida, WaLL ST. J., Nov. 28, 2000, at A12; Associated Press, Breakup of Voter News Service Urged, JSONLINE: MiLWAUKEE J. SENTINEL (Nov. 28, 2000), available at http://www.jsonline.com/election2000/ap/nov00/ap-recountvns1 12800.asp (last visited Apr. 4, 2001).

80. See id.

81. See also Jeremy Gerard, TV Networks May Approve A Pool of Election Exit Polls, N.Y. TIMES, Oct. 31, 1989, at C26; James A. Bames, The Polling Business, 5 The Public PERSPECTIVE, Nov, 1993, No. 1, at 17; Reuven Frank, Election Night; On Television, 75 THE NEw LEADER, No. 13, at 20.

82. As one news commentator observed: "When each news team talked about 'our projection' and 'our call,' it was, in effect, committing consumer fraud." Moshe Adler. Bungled Election Projection? Blame the Feds!, available at http://www.salon.com/tech/feature/2000/12/07/antitrust/index.html (last visited Dec. 7, 2000).

83. Id.

84. Id. 
all six organizations used the same basic data and the same models. Instead of six fully independent organizations trying their best to predict election results accurately, there was essentially only one. It followed that the six major news services all made the same predictions and the same mistakes.

If the six largest manufacturers of some automobiles, aluminum, or aspirin decided to close existing operations and pool resources to save money, the Antitrust Division or the Federal Trade Commission would almost certainly investigate. ${ }^{85}$ Whether the firms called their project a joint venture,

85. A similar situation arose with a court case in Israel in 1998. See Determination Pursuant to Section 43(a)(1) of the Antitust Law, 5748-1988, A Restrictive Practice Between the Second Channel News Company and the Israel Broadcasting Authority (Jan. 20, 1998) (concerning the Israeli court case). In that case, the only existing Israeli news channels, Second Channel and Israel Broadcasting Authority, agreed to coordinate their broadcasting of speeches by public officials. See id. Executives from both channels met and determined the time both would air speeches, as well as the editing of these speeches. See id. The Israeli Antitrust Commission argued that the activity was anticompetitive as it diminished the competition between the two channels for viewers. See id. However, the channels argued that their coordination aided them in their "duty to prevent public figures from 'dictating to the media what should be published, including the timing and content of such publications,' . . and . . . [avoiding] the situation of "people talking above the heads of the reporters and deciding for [the channels] when ... and ... how to have press conferences. ..." Id.

The court did not agree with the news channels and found the coordination to be a restrictive practice under Israeli antitrust law. See id. The court stated: 'Before us is a 'practice,' within the meaning pursuant to the Law - as a joint framework for the making of commercial decisions (in this case, what would and what would not be broadcast), constitutes a 'practice."' Id. Further the court stated

[i]ndeed, by the practice entered into by the Networks, the two restricted themselves in relation to each other. Each one of them denied itself, by agreement, some of the right to make autonomous decisions regarding the manner of covering events such as press conferences, taking place during peak viewing hours.

Id. Finally, the court found that "[t]he uniform front has a commercial impact, including an impact on the viewing ratings of each of the Networks. Needless to say, viewing ratings are a measure of professional-and occasionally also artistic-success, and a basis for commercial success." Id. In sum the court held that

[t]he existence of competition between the television Networks operates to the benefit of the consumer; it gives rise to competition for his preferences, and thus causes an incessant effort to cater more accurately to his taste. The prevention of competition in this case is a restrictive Id.

practice, damaging the consumer's welfare.

After the court rendered this decision, both channels appealed. Ariel Katz was one of the government's attorneys handling the appeal. He states: "Quite disappointingly, the case ended in a sort of consent decree in which the channels fundamentally agreed not to engage in any coordination of the content of their broadcast without prior notification to the Commissioner ...." E-mail from Ariel Katz to Robert H. Lande dated Nov. 12, 2000 (on file with the authors). He further commented on the impact this decision would have in Israel if those news channels created an agreement similar to that of the Voter News Service.

[I] four channels chose to supply a coordinated election prediction, they would have to notify their intention to the Commissioner who would be able to challenge it. As it seems, we have only 2 news channels in Israel but their separate assessments on election nights really marks and highlights the competition between them. 
merger, or consortium, it would be scrutinized carefully under the antitrust laws. Why should the Voter News Service be any different?

Under the recently issued federal Antitrust Guidelines For Collaborations Among Competitors ${ }^{86}$ the legality of the Voter News Service essentially would be judged under the rule of reason, an analysis that considers all of a joint venture's benefits and costs. The defendants would no doubt point out that the anticompetitive harm from most cartels is higher prices, but that they did not raise prices. They only saved costs.

But they also decreased consumer choice. When considering the prospect of too little competition in the news market, very little weight should be given to the defense that the colluders (or, if you prefer, joint venture partners) will save money.

In its defense, the Voter News Service might point out that in 1945 the Supreme Court held that it was legal for dozens of newspapers to help form and participate in the Associated Press. ${ }^{87}$ The Associated Press is able, however, to create some venture-specific efficiencies by doing a large number of crucial things (e.g., sending reporters to the far corners of the globe) that few individual newspapers could afford by themselves. While news gathering organizations can legally work together under these circumstances, this defense would not apply to the Voter News Service because, before its formation, each of the major news organizations had in fact been able to make independent election predictions.

If there were six truly competing organizations today, they might come up with any number of innovative techniques for predicting elections. ${ }^{88}$ Instead of largely competing to be the first to call a state (as is sometimes alleged), news organizations might also compete to be the most accurate. They would certainly have an increased incentive to do so. If only one

Id.

86. Antitrust Guidelines For Collaborations Among Competitors, Federal Trade Commission and the U.S. Department of Justice (Apr. 7, 2000), available at http://www.ftc.gov/os/1999/9910/ jointventureguidelines.html.

87. See Associated Press v. United States, 326 U.S. 1 (1945).

88. Moshe Adler observes that

[m]ost events require coverage from different angles in order for the public to get a full picture, and even then, most stories are too complex for the kind of postmortem applied to the election prediction. When angles are missing, how is the public to know that anything is amiss?

$\ldots$

... [T] extbook economics is built on the assumption that consumers are fully informed about the quality of the product they are getting. Such is not the case in the media: If consumers are offered only a few sources of news, how can they know what they're missing?

Adler, supra note 82. 
network had made a seriously wrong prediction, they would risk becoming the butt of Jay Leno "Dewey defeats Truman" jokes for months. Since they all erred equally, however, no one network will suffer very much. They know they have not been hurt relative to their competitors, and this lack of relative harm may be the most important factor in a competitive market.

Firms in the media sector have announced a striking number of large mergers in recent years. As each merger is announced, questions arise as to whether this crucial sector is getting so concentrated that the variety of independent news sources is too low. ${ }^{89}$

The largest media sector merger ever announced was that between America Online and Time Warner.90 The FTC ultimately approved this merger, but only after imposing a number of conditions, that clearly were

89. An unusual example may be that of supermarket tabloids. Due to a recent merger, all of the major supermarket tabloids are now owned by one company. American Media, Inc. owns the National Enquirer, Star, Globe, National Examiner, Sun and Weekly World News. Rather than continuing to compete with one another, each publication reportedly will specialize in one niche of the tabloid market. For example, the Enguirer will focus on Hollywood news, the Sun will use health and religious stories to appeal to the 55+ audience, and the Weekly World News will concentrate on stories involving aliens, UFOs, and Elvis. See Sensationalism Six Pack: One Company Owns All the U.S. Supermarket Tabloids, SKEPTICAL ENQUIRER, 8, Jan./Feb. 2001, quoting the AMERICAN JOURNALISM REVIEW, available at http://ajr.newslink.org/ajrdarciesept00.html.

In addition, the author of a critical biography of Michael Eisner, CEO of Disney Corp., recently charged that she is being boycotted by Disney-owned publications. If true, this conduct could be an example of the kind of abuse that arises from undue media concentration. In the extreme, this type of behavior could even threaten the free competition of ideas in our society. See Eisner Biographer Mousetrapped?, WASH. POST, Mar. 16, 2000, at C3.

Other specialty media markets also are showing signs of increased concentration. For example, the world of gay and lesbian media has consolidated markedly over the last six years. The proposed merger of Liberation Publications with Planet Out, each with a history of mergers and acquisitions, is illustrative of this trend. On November 15, 2000, the two largest Internet companies targeting this market, Planet Out and Gay.com, announced their merger. This merger created a media outlet with 1.6 million registered users that reaches 3.5 million individuals a month. The nearest competitor, Gaywired.com, has a mere 500,000 users. Prior to this merger, Planet Out had already subsumed OnQ, another large on-line service, and purchased a substantial share of Gay Financial Network (gfn.com). Meanwhile, in 1996, Los Angelesbased Liberation Publications (LPI), publisher of the Advocate, purchased Boston based Alyson Publications, the oldest gay and lesbian trade book publisher in the country. In April, 2000, LPI purchased its largest competitor, New York-based Out magazine, creating a company with a joint circulation of $\mathbf{2 0 0 , 0 0 0}$, or roughly five times greater that its closest competitor. In February of 2000, LPI and Planet Out announced their merger, a deal which as of February 2001 is still not final. In response to increased concentration in this specialized media market, community advocates are urging members of the gay and lesbian community to contact the Antitrust Division of the Department of Justice to complain. See Michael Bronski, Gay Media Monopoly, at http://www.Zmag.org/commentaries (last visited Feb. 18, 2001 ).

90. For an analysis of many of the antitrust issues involved in this merger, see Statement of Robert H. Lande made at the Hearing on the America Online/Time Wamer Merger before the Committee on Commerce, Science, and Transportation, United Sates Senate (Mar. 2, 2000). 
based on consumer choice concerns. That consumer choice was the key consideration is well supported by the statements of the FTC Commissioners both before and after the merger's approval. Chairman Robert Pitofsky noted that "[o]ur concern here was with access, that these two powerful companies would create barriers that would injure competitors of Time Warner and competitors of AOL.... If you don't block anticompetitive arrangement early on, then it becomes impossible or too expensive later on to do anything about it."

Two issues involving consumer choice were of preeminent substantive importance. First, several Commissioners were concerned with preventing AOL-Time Warner from using its significant market share in the cable market to gain a "first mover" advantage against potential broadband Internet competitors. Secondly, the Commissioners were concerned that AOL-Time Warner would use its market power to interfere with content on broadband or interactive TV transmissions. The FTC exacted several concessions from the new company to prevent these practices from occurring. As Chairman Pitofsky pointed out, "[t]his settlement would preserve competition and protect consumers from higher cable service prices and reduce programming choices by ensuring that competing cable operators, new technologies, and future programmers can gain access to Time/Turner's customers and programming." 92

91. FTC backs AOL-Time Warner merger, THE JOURNAL,RECORD, Dec. 15, 2000, available at 2000 WL 14300520.

92. Jaret Seiberg, Time Warner, AOL Deal Rankles Lawmakers, N.Y. L.J., Jan. 11, 2000, at 1, available at http://www/law.com/cgi-bin/gx.cgi/ (last visited Apr. 4, 2001). See also FTC Approves APLTime Warner Merger With Conditions, FTC News Release, Dec. 14, 2000, available at $2000 \mathrm{WL}$ 1836342 (F.T.C.) (" $[O]$ ur concern was that the merger of these two powerful companies would deny to competitors access to this amazing new broadband technology .... This order is intended to ensure that this new medium, characterized by openness, diversity and freedom, will not be closed down as a result of this merger.").

Commissioner Pitofsky's statements were closely echoed by the statements of other Commissioners. In his concurring statement to the FTC's consent, Commissioner Thompson stated: "I voted to accept the settlement, however, because the consent will not only provide a means to address these concerns, but will also send an important message to the market that high speed internet should continue to provide consumers with choice of service and diversity of content." In the Matter of America On Line, Inc./Time Warner, Inc., No. C-3989, 2000 WL 1843019 (F.T.C.) (Dec. 14, 2000) (Concurring Statement of Commissioner Mozelle W. Thompson). In a later statement, Commissioner Thompson reiterated that the agreement was not as broad as he would have wished. AOL Merger Clears Last Big Hurdle; FTC Mandates Open Access To Time Warner's Cable, WASH. POST, Dec. 15, 2000, at A01, available at http:// washingtonpost.com/wp-dyn/business/industries/media/aoltimewamer/archive/. Commissioner Thomas B. Leary, one of the two Republican Commissioners, agreed: "I acknowledge that I had and I continue to have concerns about these content issues ...." Id. Commissioner Orson Swindle, considered by many to be the more conservative, pro-business of the Commissioners, said that the ideologically divided 
Together, the Voter News Service and AOL/Time Warner matters prompt the question whether things have gotten to the point where a mistake or bias can no longer be corrected by the normal give and take of competition among media firms. They serve to remind us that optimal levels of consumer choice, in addition to price effects, can be of crucial importance in this market.

At some point an antitrust suit might properly challenge further consolidation. ${ }^{93}$ Such a suit would not seek to apply a special standard for the media that is based on First Amendment or diversity considerations. ${ }^{94}$ Rather, it would be based on the ordinary, universal standards of Section 7 once properly construed to recognize the roles of consumer choice and non-price competition. This lawsuit should include the short-term idea of providing

commission "found the compromise" it needed in the terms of the agreement. See David McGuire \& Robert MacMillan, AOL-TW Deal Setup Allays Many Consumer Worries, NEWSBYTES NEWS NETWORK, Dec. 14, 2000, also available at $2000 \mathrm{WL} 27303933$. Swindle added that the Commission would stand by and enforce the agreement regardless of who headed the Agency in the new administration. Id.

93. Both the National Broadcasting Company ("NBC") and the Central Broadcasting Service ("CBS") independently investigated the actions of the VNS on election night 2000. See NBC News Releases Summary of Election Night Review, Jan. 04, 2001, available at http://www.nbcmv.com/pw2/main (last visited Mar. 10, 2001); Linda Mason et al., CBS News Coverage of Election Night 2000: Investigation, Analysis, Recommendations, Jan. 2001 (on file with the author).

Regarding the mistaken data received from the VNS, NBC found that, although "VNS's fundamental methodology is sound, its system needs improvement, including a computer upgrade." NBCNews Releases Summary of Election Night Review, supra. To that end, NBC was willing to provide its share of funding to support the upgrade. See id. In addition. NBC found that its internal policies must be revised to facilitate its efforts in projecting election results. See id. These policy changes include "not project[ing] a winner in a state until after the last scheduled poll closing time in that state, . . . [defining] terms (like 'projection' or 'too close to call'), ... explain[ing] the methodology for collecting the data it presents, [and using] other available news sources, such as AP." Id. The report concluded that, "[t]he lesson from Election Night 2000 is that sufficient resources must be in place to ensure the reliability of NBC's Election Night reporting in the future," and that "[b]eing right, not first, is what matters." Id.

CBS News similarly reviewed the election night debacle. See Linda Mason et al., supra. In its analysis, CBS found that to avoid similar problems in the future, it must:

strengthen management oversight of the Decision Desk ..., modify the language and graphics used on-air to call races, making clear that CBS calls are estimates, not facts, ... withhold an official call until all the polls have closed in [a state with multiple closing times], ... invest additional resources in key states with close races. ... [and] either invest additional resources to fix problems at VNS or build an alternative service with a new consortium.

See id. at 4-5. Specifically regarding the problems at VNS, CBS found that, "VNS, in a preliminary review, [cited] its own imperfections: problems with the sample, with the equipment, with the software and with quality control." See id. at 31. The findings of both these reports highlight the internal problems faced by VNS, and lead to the question of whether those problems would have been borne out by the market and fixed had competition existed for accurate election night exit polling.

94. Cf. Associated Press v. United States, 326 U.S. 1, 20 (1945) (First Amendment considerations support application of the Sherman Act to the media, since both provisions are intended to encourage diversity, although the media context did not alter ordinary Sherman Act standards.). 
consumers with a competitive array of options, as well as the long-term notion of fostering the optimal level of innovation.

\section{CONCLUSIONS}

Trade regulation law is ultimately about choice, and the discipline of antitrust law is best defined in terms of its role in this process. An antitrust violation best can be understood as an activity that unreasonably distorts or restricts the options that otherwise would be available to consumers.

The goal of this article is to help shift the focus of antitrust from the current administrative and judicial emphasis on price to one that centers around the concept of consumer choice. Although price competition is often of utmost importance to consumer welfare, so too is the variety, quality, and innovation of products. Regrettably, antitrust enforcement and legal decisions have sometimes treated non-price attributes as afterthoughts, when they actually should have been at the forefront of legal debate and analysis. As the Microsoft case and other current cases discussed in Section III demonstrate, antitrust case law has already begun to move explicitly towards a consumer choice model. The particular implementation of the choice approach, however, must await further analysis. 